

\section{Medical Humanity and Inhumanity in the German-Speaking World}




\section{FRINGE}

Series Editors

Alena Ledeneva and Peter Zusi, School of Slavonic and East European Studies, UCL

The FRINGE series explores the roles that complexity, ambivalence and immeasurability play in social and cultural phenomena. A crossdisciplinary initiative bringing together researchers from the humanities, social sciences and area studies, the series examines how seemingly opposed notions such as centrality and marginality, clarity and ambiguity, can shift and converge when embedded in everyday practices.

Alena Ledeneva is Professor of Politics and Society at the School of Slavonic and East European Studies of UCL.

Peter Zusi is Associate Professor of Czech and Comparative Literature at the School of Slavonic and East European Studies of UCL. 


\section{Medical Humanity and Inhumanity in the German-Speaking World}

Edited by Mererid Puw Davies and Sonu shamdasani 
First published in 2020 by

UCL Press

University College London

Gower Street

London WC1E 6BT

Available to download free: www.uclpress.co.uk

Text (C) Contributors, 2020

Images (C) Copyright holders named in captions, 2020

The authors have asserted their rights under the Copyright, Designs and Patents Act 1988 to be identified as the authors of this work.

A CIP catalogue record for this book is available from The British Library.

This book is published under a Creative Commons Attribution Non-commercial Nonderivative 4.0 International licence (CC BY-NC-ND 4.0). This licence allows you to share, copy, distribute and transmit the work for personal and non- commercial use providing author and publisher attribution is clearly stated. Attribution should include the following information:

Davies, M.P. and Shamdasani, S. (eds.). 2020. Medical Humanity and Inhumanity in the German-Speaking World. London: UCL Press. DOI: https://doi.org/10.14324/111. 9781787357716

Further details about Creative Commons licences are available at http://creativecommons.org/licenses/

Any third-party material in this book is published under the book's Creative Commons licence unless indicated otherwise in the credit line to the material. If you would like to reuse any third-party material not covered by the book's Creative Commons licence, you will need to obtain permission directly from the copyright holder.

ISBN: 978-1-78735-773-0 (Hbk.)

ISBN: 978-1-78735-772-3 (Pbk.)

ISBN: 978-1-78735-771-6 (PDF)

ISBN: 978-1-78735-774-7 (epub)

ISBN: 978-1-78735-775-4 (mobi)

DOI: https://doi.org/10.14324/111.9781787357716 


\section{Contents}

List of figures vii

Notes on contributors viii

Preface $\quad$ xi

1. Medical In/Humanities: The Human and the Humane in the German-Speaking World. An Introduction

Mererid Puw Davies and Sonu Shamdasani

2. Pain and Laughter: Dental Treatment as a Comic Motif in Medieval and Early Modern Literature

Sebastian Coxon

3. Combat, Military Medicine and Psychiatric Disorders during and after the Wars of Unification

Mark Hewitson

4. From Neurosis to a New Cure of Souls: C.G. Jung's Remaking of the Psychotherapeutic Patient

Sonu Shamdasani

5. C.G. Jung and the Berneuchen Movement: Meditation and Active Imagination in Jungian Psychotherapy and Protestant Spiritual Practice in the 1930s

Martin Liebscher

6. Humane Horrors: The Dentist in Günter Grass's örtlich betäubt / Local Anaesthetic (1969)

Mererid Puw Davies

7. Inhumane Institutions: Wilhelm Genazino's Clinical

Treatments

Thomas Wilks 
8. Medical Experiments on Humans in Kerstin Hensel's Lärchenau (2008)

Ernest Schonfield

9. Burnout Therapy, Cool Conduct and Cold Cinema Annie Ring

Index 
8

\section{Medical Experiments on Humans in Kerstin Hensel's Lärchenau (2008)}

Ernest Schonfield

\section{Preface}

Medical humanities in a German-speaking context are obliged to reflect upon the active participation of the medical profession in the euthanasia and genocide of the Third Reich. This chapter examines the legacy of Nazi medical crimes in Kerstin Hensel's Lärchenau, a novel set in East Germany before and after German reunification in $1990 .^{1}$ Its fictional character Dr Konarske cannot be described as a Nazi, since he is born in 1944 and has no obvious political affiliation. Yet he conducts medical experiments on women that bear a certain resemblance with the medical crimes, sterilisation and fertility programmes of the Nazi regime. Drawing on the work of Alexander and Margarete Mitscherlich, this chapter argues that the characters in the novel repeat sadomasochistic behaviour patterns because they have repressed their own childhood traumas and those of their parents: the work of mourning has yet to be done.

In so doing, this chapter forms connections with other contributions in this volume. First, Mark Hewitson's contribution investigates post-traumatic stress disorder in the context of the wars of the 1870s. This chapter, by contrast, explores trauma among civilian populations, arguing that Hensel's fiction offers insights into long-term behavioural problems caused by intergenerational domestic violence. Second, the focus in the following on the Mitscherlichs also offers an alternative psychoanalytical approach to that of C.G. Jung. While Martin Liebscher and Sonu Shamdasani examine how Jung fosters personal development by engaging with religion and myth, this chapter is informed instead by the Mitscherlichs' psychoanalytic study of the residual libidinal 
attachment to authority figures in West Germany of the 1950s and 1960s, an approach that resonates with the social psychology of the Frankfurt School. A similar critique of authoritarianism can also be applied to the GDR, as Margarete Mitscherlich and Brigitte Burmeister have argued in Wir haben ein Berührungstabu / We Have a Fear of Touching. ${ }^{2}$ Third, Hensel's novel has affinities with Katharina Pethke's documentary film In dir muss Brennen / Burning Within (2009), analysed in Annie Ring's chapter, since both works represent 'inhuman' medical practices, whereby human beings become subordinated to so-called 'objective' concerns (whether these are economic, as in Pethke's film, or scientific/eugenic, as in Lärchenau).

Fourth, and finally, this chapter complements Mererid Puw Davies's analysis of Günter Grass's post-war West German novel örtlich betäubt. Davies shows that the legacy of National Socialism was a key term in political debates around 1968 in West Germany, whereby each side (the government, the student activists) sought to undermine the other by associating them with National Socialism. The West German political establishment denounced activists by asserting their connections with totalitarianism and extremism, while the activists pointed out that many members of the West German establishment had little claim to moral authority because of their actions during the so-called Third Reich. Davies notes that the dental profession had brought itself into disrepute by the collaboration of some of its members with the Nazi regime (this connection is exemplified also by the character of Dr Szell in the Hollywood film Marathon Man, 1967). Taken together therefore, Davies's chapter and this one reassess the uncomfortable implications of the Nazi legacy for the medical professions in both post-war German states.

\section{Introduction}

Sie fing zu murmeln an. Über die Versuche an weiblichen Häftlingen. Über die Spätschäden. ${ }^{3}$

She started to mumble. About the experiments performed on female prisoners. About post-traumatic disorders. ${ }^{4}$

During the so-called Third Reich, the German medical profession was implicated in genocide, mass murder and euthanasia programmes. The Nuremberg Doctors' Trial - 9 December 1946 to 20 August 1947 - was 
documented by Alexander Mitscherlich and Fred Mielke as early as 1947, with a revised edition appearing in $1960 .{ }^{5}$ Until the early 1960 s, however, discussion of National Socialist crimes focused mainly on Hitler and senior Nazi officers. After the trial of Adolf Eichmann in Jerusalem in 1961, the definition of a Nazi perpetrator was expanded to include administrators. ${ }^{6}$ This trial, and the subsequent Frankfurt Auschwitz trials (1963-5), encouraged historians to turn their attention to the middle managers of the genocide. Major studies of Nazi medical crimes appeared in the following decades. ${ }^{7}$ Henry Friedlander considers the Nazi sterilisation programmes and euthanasia of the handicapped as a preliminary step towards genocide. ${ }^{8}$ More recently, Paul Weindling has studied the archival testimonies of the victims of medical crimes, many of whom were Polish, Sinti and Roma, in addition to Jews. ${ }^{9}$

The legacy of Nazi medical crimes is explored in Ingeborg Bachmann's unfinished novel Das Buch Franza / The Book of Franza (written 1965-6, first published as Der Fall Franza in 1978, published as Das Buch Franza in 1995). The protagonist, Franza Ranner, marries the psychologist Leopold Jordan, a specialist in treating Holocaust victims. He encourages her to research the Nuremberg Medical Trials and engineers her mental breakdown. While the opening of Franza adopts the perspective of Franza's brother, Martin Ranner, much of the book is also narrated by Franza herself. She is an unreliable narrator, but she clearly identifies as an animal-like test subject:

Wie habe ich mich benommen, wie ein Tier, das in seinem Käfig auf- und niederrennt, und wenn ich die Stäbe hätte durchrennen können mit meinem Schädel, wäre ich noch im Käfig gewesen, in den Käfig seiner Notizen, die mich verfolgten... ${ }^{10}$

I felt like an animal that runs back and forth in its cage, and even if I'd been able to crash through the bars with my head, I would have still been in a cage, in the cage of his notes which followed me ... ${ }^{11}$

Franza is convinced that abuse is still widespread in post-war Austrian society. She claims that sadists and criminals are 'among us', working within the law, under the cover of professional ethos:

die Sadisten [sind] nicht nur auf psychiatrischen Abteilungen und in den Gerichtssälen zu finden, sondern unter uns ... mit blütenweißen Hemden und Professorentiteln, mit den Folterwerkzeugen der Intelligenz. ${ }^{12}$ 
sadists are found not only in the psychiatric hospitals and in the courts, but also here among us with snow-white lab coats and titled professorships, armed with the intelligentsia's tools of torture. ${ }^{13}$

Such comments are relativised by Franza's post-traumatic disorder and her unreliability as a narrator. Nevertheless, there are clear textual parallels between her experience and Nazi medical crimes, for example, her husband's sadism and his lack of remorse. ${ }^{14}$ Ironically, according to Franza, in the Nuremberg medical transcripts, the words 'forgive me' only ever occur when one of the victims apologises for crying in court. ${ }^{15}$ Later, Franza escapes to Egypt, where she encounters an actual perpetrator, the former SS doctor Kurt Körner. Stephanie Bird argues that Franza's submissiveness and self-deception make her complicit in her own destruction. ${ }^{16}$ Das Buch Franza reveals 'the mechanisms through which individuals, in this case a woman, willingly become subservient to power, and comply with it by mistaking it for or choosing to see in it a moral authority. ${ }^{17}$ In this way, Bachmann's approach to the problem of complicity with fascism subverts the crude dichotomy of victims and perpetrators.

This approach resembles the psychological perspective adopted by Alexander and Margarete Mitscherlich in Die Unfähigkeit zu trauern (1967) / The Inability to Mourn (1975). ${ }^{18}$ The Mitscherlichs examined the extent to which the general population had invested themselves psychologically in the Nazi regime. They concluded that much 'Trauerarbeit' / 'work of mourning' was still required before Germans could overcome recurrent authoritarian patterns in their interpersonal relationships. The Mitscherlichs' work inspired some West German feminists to reflect on women's collusion with patriarchy; for example, the Hamburg women's collective around Frigga Haug argued that collective 'Erinnerungsarbeit' / 'memory work' should inform the social sciences. ${ }^{19}$

These authors pointed the way beyond categorical oppositions between women and patriarchy, and raised the controversial possibility that many 'ordinary' Germans were complicit with National Socialism. However, it was not until the late 1980s that studies appeared on women's participation in the so-called Third Reich. Whereas Gisela Bock considered that forced sterilisation programmes had presented women primarily as victims of Nazism, Claudia Koonz's Mothers in the Fatherland (1987) studied middle-class women who played an active part in the formation of the Third Reich. ${ }^{20}$ The ensuing debate between Bock and Koonz hinged on the question of whether women were victims of Nazism or its supporters. The debate exemplified the transition from Bock's essentialist model of feminist history, which considered women's history 
in categorical opposition to patriarchy, to Koonz's more nuanced gender studies approach, implying that certain aspects of National Socialist family policy could be seen as responding to the conservative wing of the German women's movement. ${ }^{21}$ Some campaigners had regarded the recognition of motherhood as 'woman's highest calling' as a precondition for social improvement, a discourse also adopted by the Nazis. ${ }^{22}$ These findings indicate the importance of sustained memory work for the humanities, and literary fiction, with its irony, ambiguity and reflectivity, offers a highly nuanced approach to National Socialism and its after-effects.

This chapter focuses on the representation of medical experiments on humans in Kerstin Hensel's Lärchenau (2008). Hensel previously addressed the theme of the 'fascist doctor' in her unpublished work Karzinom / Carcinoma (1981), an absurd drama recalling the plays of Friedrich Dürrenmatt, set in an East German clinic. ${ }^{23}$ Lärchenau develops this preoccupation in a much more subtle way, by exploring the childhood development of the main protagonists. At the centre of Lärchenau is the East German doctor, Gunter Konarske, and his wife, Adele, née Möbius. Konarske conducts a series of medical experiments on women without their knowledge: on nurse Angela, wife of the local physician Dr Krause, and then on Adele. The novel's title, Lärchenau, refers to a fictional village in Brandenburg, near Storkow in the Oder-Spree district. The protagonists' childhood experiences set up behavioural patterns that are repeated in later life. Adele and Gunter are born in 1944 and never meet their fathers, and are thus in search of ideal father figures, as described by Alexander Mitscherlich in Auf dem Weg zur vaterlosen Gesellschaft / Society Without A Father (1963), which describes difficulties faced by Germans after 1945 in adapting to a world in which paternal authority was either absent or diminished. ${ }^{24}$ Gunter constructs an ideal image of his deceased father, who was acclaimed by the villagers as a 'Zauberer' / 'magician' $(L, 71)$, while Adele regards Adolf Hitler as a father figure. The long time span of Lärchenau - it begins in 1944 and ends in the year 2007 - enables Hensel to suggest that there are enduring continuities in German history, and even that some things get worse after the reunification of Germany, which occurs two thirds of the way through the novel.

On one level, Lärchenau is a tribute to Bachmann's Das Buch Franza. In both novels, the female protagonist is subjected to unethical medical experiments by her husband. In both cases, the female character's susceptibility to authoritarian dominance is traced back to her early childhood. Both girls fantasise about mythical princes and king-like figures, and this prepares them to play a subservient role in adult life. In both texts, the women flee to the Middle East in order to escape their sadistic husbands - Adele travels to Amman, the capital of Jordan, a discreet allusion 
to Leopold Jordan in Franza ( $L, 406-12)$. Both novels are set mainly after 1945: they do not explore Nazi medical crimes themselves; instead, they consider the long-term repercussions of these crimes and the repetition of patterns of violence in recent German and Austrian history. The novels are also linked by the view that violence (particularly sexual violence) is an inescapable aspect of human existence. Bachmann describes society as a 'Mordschauplatz' / 'murder scene', ${ }^{25}$ and Birgit Dahlke argues that in Hensel's fiction, sexual violence is an instance of an omnipresent violence in human relationships. ${ }^{26}$ Thus for both Bachmann and Hensel, violence is not limited to the crimes of dictatorships (whether the 'Third Reich' or the GDR); it is a pervasive feature of human existence.

Despite these similarities, there are major differences between Lärchenau and Das Buch Franza. Whereas Bachmann's text focuses on psychiatric abuses in Vienna, Hensel's novel focuses on abuses in fertility treatment and genetic research in East Germany. In Das Buch Franza, the subjective experiences of the main protagonist are foregrounded, and Franza herself is the unreliable narrator of the latter half of the book. In Lärchenau, the impersonal third person narrator grants only limited access to the characters' thoughts. Furthermore, while Das Buch Franza addresses the Holocaust explicitly, in Lärchenau the Holocaust is only referred to in passing. There is something shockingly casual about the references to the Holocaust, for instance when the Jewish tailor Simson Blumgebind returns home from a concentration camp and dies in the arms of Rosie Konarske $(L, 59)$, or when someone notices that the elderly Roma woman Mitschka Prohaska ${ }^{27}$ has a number tattooed on her arm $(L, 353)$, and wonders if it is a telephone number. In Lärchenau, the typical response to the Holocaust is either indifference or incomprehension.

Perhaps the most striking difference between the two texts, however, is that Lärchenau covers a much greater time span. While Das Buch Franza covers the period from the early 1940s to 1965, Lärchenau begins in 1944, before jumping back to Adele's mother's childhood at the beginning of the twentieth century, and the winter of 1915, when Adele's grandfather Benno Möbius died while serving in Wallachia $(L, 22)$. Lärchenau then follows the lives of its characters all the way through to August 2007, covering a time span of nearly a century. Hensel's critical engagement with the past is thus exemplary in terms of its longue durée. Like Michael Haneke's film Das weiße Band / The White Ribbon (2009), Hensel takes the period around the First World War as a starting point in order to suggest the existence of long-term structural violence in German history and culture.

This chapter offers an interpretation of Lärchenau drawing on the historical record of Nazi medical atrocities and their literary reception by 
Bachmann and Hensel. This approach is intended to act as a corrective to the tendency to label Hensel's work as a form of 'grotesque satire'. ${ }^{28}$ Typically, reviews of Lärchenau stress its humorous, 'baroque' or 'mythological' qualities. ${ }^{29}$ Satire, legend and fairy tale are popular literary genres. Reading Hensel's prose in these generic terms risks reducing it to an amusing, eccentric curiosity, an example of lowbrow fiction. This chapter seeks to counter this existing critical trend, reading Lärchenau as a complex, serious and challenging text and an important instance of critical Vergangenheitsbewältigung / 'coming to terms with the past'. It will argue that, far from being an exaggeration, Lärchenau is actually rather restrained in its depiction of the endemic acts of violence of German history. We will first address narrative technique and genre, before turning to a brief examination of the historical record. This will lead to a discussion of moral complicity and the wider implications of the novel's representation of fertility experiments and cell rejuvenation.

\section{Narrative Technique and Genre}

The narrative technique of Lärchenau is varied: much of the dialogue is in regional dialect, and the narrative switches frequently between the large cast of characters. The narrative speeds up during German reunification, focusing in particular on the events of one month, August 1990 ( $L, 272-7)$. There is a preference for lists of three elements, conveying a sing-song quality, for example when Gunter goes away and leaves Adele alone, it could be: 'Für Tage. Oder Wochen. Oder Monate. Nie war es vorauszusehen' / 'For days, or weeks, or months. It could never be predicted' $(L, 292)$. Despite some formal experimentation, however, much of Lärchenau is narrated in a fairly straightforward manner. The timeline is mostly linear, focusing mainly on the period from 1944 to 2007, although the text also depicts the childhood of the Möbius sisters in the first decades of the twentieth century, and the courtship of Gunter's parents in the early 1940s. The detached third-person narrator reels off the events rapidly as they occur, without emphatic commentary. The opening adheres to realist conventions, offering a precise description of Lärchenau's geographical location and its lack of tourist attractions $(L, 7)$. However, despite these traditional narrative conventions, Hensel's texts are notable for their graphic imagery and depictions of sex, violence and sexual violence. In Hensel's works, everyday life in Eastern Germany, before and after the turning points of 1945 and 1989, is characterised by violent, oppressive behaviour. 
Hensel's work is often interpreted in terms of the grotesque. Lyn Marven focuses on the grotesque as a manifestation of trauma, also observing that the grotesque body has the potential to transgress the confines of totalitarian ideologies. ${ }^{30}$ Jill E. Twark also emphasises Hensel's use of the grotesque, pointing out that Gipshut / Plaster Cap (1999) features a character with an abnormally large body due to a hormone imbalance - an inversion of the dwarf Oskar Matzerath in Günter Grass's Die Blechtrommel / The Tin Drum (1959). ${ }^{31}$ Indeed, Hensel's texts, with their anarchic and subversive imagery, have often been compared to those of Günter Grass ${ }^{32}$ and Irmtraud Morgner. ${ }^{33}$ Even so, in 2007 Twark observed that Hensel's more recent texts have become less grotesque, bucking the grotesque trend of the 1990s. ${ }^{34}$ However, Twark does not develop this point, and her interpretation of Gipshut focuses almost entirely on the grotesque. Furthermore, in an essay of 2015, Twark characterizes Lärchenau as an instance of 'grotesque satire'. ${ }^{35}$ Hensel, like Grass, does use satire, for instance while Grass's novel Hundejahre / Dog Years (1963) uses dog breeding to satirise Nazi aspirations to breed a Nietzschean Übermensch, Hensel's Lärchenau adopts a similar procedure, using pig farming to poke fun at the socialist ideal of 'der neue Mensch' / 'the new human'. ${ }^{36}$ Like the work of Grass, Hensel's work does contain a vein of robust, earthy satire. But nobody would pigeonhole Grass as a mere 'satirist'. To read Hensel in this way is reductive.

Categorising Hensel's work as satire risks trivialising it. Heinrich Mann's reputation as a satirist has not translated into canonical status. When Hensel's Falscher Hase / Meat Loaf (2005) is compared to Heinrich Mann's Der Untertan / The Loyal Subject, this only reminds us that he lacks the canonical status of Thomas Mann. ${ }^{37}$ Indeed, categorising Der Untertan as a satire is a means to dismiss it as a 'low' form of art, making it easier for critics who disagree with its political analysis to write it off as a mere curiosity. ${ }^{38}$ Kurt Tucholsky argued that Der Untertan is not a satire or a caricature, but 'modest photography'. ${ }^{39}$ The purpose of this chapter is to mount a similar defence of Lärchenau. What happens if we read the grotesque imagery of Lärchenau not as an exaggeration or a distortion, but as an accurate depiction of 'real existing' violence? This chapter argues that the obscenity in Lärchenau is justified by the obscenity of the historical record.

\section{Eugenics Experiments on Humans - The Historical Record}

There is a long history of medical experimentation on humans, particularly in the modern period. ${ }^{40}$ Today, medical trials on human beings comprise a global industry, with many of the most dangerous trials carried 
out on subjects in developing countries. ${ }^{41}$ For our purposes, however, a brief historical sketch will suffice. The first eugenic organisation in the world was the Gesellschaft für Rassenhygiene / Society for Racial Hygiene, founded in Berlin in 1905. The term 'racial hygiene', coined by Alfred Ploetz, was understood in terms of racial purity, and the improvement of public health..$^{42}$ During the Weimar Republic, eugenics informed the development of the welfare state. This trajectory was informed by a new national centre for eugenics, the Kaiser-Wilhelm-Institut für Anthropologie / Kaiser Wilhelm Institute for Anthropology, founded in 1927, also in Berlin. These eugenicists tended to be 'unrepentantly meritocratic' and elitist, attempting to replace universal social welfare with selective welfare benefits for social elites. ${ }^{43}$ When the National Socialists came to power, they embraced eugenics, passing a sterilisation law in July 1933 under the supervision of the psychiatric geneticist Ernst Rüdin. ${ }^{44}$ The Kaiser-Wilhelm-Institut für Anthropologie ran training courses for SS doctors in 1935-6 in the implementation of racial policy. ${ }^{45}$ Sex hormone research and fertility control were central to this policy. Two notable war criminals were Karl Gebhardt (1897-1948) and Carl Clauberg (1898-1957), who conducted medical experiments on prisoners in Ravensbrück and Auschwitz respectively. Karl Gebhardt, for example, extracted foetuses from 350 forced labourers. ${ }^{46}$

However, Clauberg is particularly relevant for our discussion. The flip side of Nazi extermination, euthanasia and sterilisation programmes was research into fertility. His early research on female hormones in the late 1920s led to the development of infertility treatments Progynon and Proluton ${ }^{47}$ In the 1930s, he regularly checked the wives of SS officers for their fertility. In the same decade, he worked at the women's clinic in Königsberg, where he sterilised large numbers of women. ${ }^{48}$ On 22 March 1940 he met with Himmler and advocated his hormone research to advance the reproductive potential of the SS. Himmler is said to have asked Clauberg if he could also reverse fertility by chemical means. ${ }^{49}$ Clauberg promised to try, and began animal experiments. In May 1942, Himmler offered Clauberg facilities at Ravensbrück, but Clauberg persuaded him that Auschwitz would be more practical because of its proximity to his clinic in Königshutte..$^{50}$ And so in 1942, Clauberg was given control over an entire block at Auschwitz: Block 10. There, Clauberg directed the mass sterilisation programme, which included forced abortions on Eastern European workers, Jews, Roma and Sinti. At the height of the programme, he had around three hundred women under his control. His method was 'to inject a caustic substance into the cervix in order to obstruct the fallopian tubes'; this was formalin, sometimes injected 
together with novocaine. ${ }^{51}$ The total number of women estimated to have been sterilised ranges from seven hundred to 'several thousand'; many of the injections were fatal. ${ }^{52}$ According to the nurse Sylvia Friedman, when a woman died after an injection, Clauberg 'showed absolutely no interest, no reaction, as through the matter didn't concern him at all. ${ }^{53}$ He worked simultaneously on fertilisation and sterilisation programmes, in 1944 becoming director of a new institution known as the 'City of Mothers'. ${ }^{54}$ In 1945 he was captured by the Soviets and spent 10 years in prison in the USSR. Repatriated with other Germans in 1955, he lived another 2 years to boast about his scientific achievements to the press. ${ }^{55}$ After 1945, 'racial hygiene' was rebranded 'human genetics', and rehabilitated, with a focus on genetic malformations. ${ }^{56}$

The case of Clauberg, with his two-pronged approach towards fertilisation and sterilisation, shows the extent to which high-ranking Nazis regarded their own wives as breeding animals similarly to the way that they regarded female prisoners in the camps. The crucial difference was that the wives were considered to belong to the correct breed and therefore their fertility was to be maximised, whereas the Eastern European, Jewish, Roma and Sinti women in the camps were considered to belong to undesirable breeds and were therefore to be made infertile by means of forced sterilisation. The sterilisation victims were not told, and did not know, that they were the subjects of a medical experiment. The plot of Lärchenau conforms to this procedure: the female protagonist Adele does not know that her husband is using her as an experimental subject - first for his fertility treatments and, later on, for his experimental anti-aging serum. Konarske, however, differs from Clauberg in that he does not subscribe to the racial ideology of the Nazis. He remains detached from ideology as well as from his victims' suffering. His primary motivation is not ideology, but the narcissistic quest for scientific glory.

\section{Victimisation and Complicity}

The sexual objectification of women by the Nazis effectively turned the female body into an instrument for the expression of the male will. Konarske is a sadist in a similar vein to Jordan in Das Buch Franza. He embarks on his medical career at the age of 13, treating the local farmers and their livestock, and seeing little difference between them. When the local farmer Helmar Eden - the surname is ironic - asks Konarske if he can cure Beate, his invalid wife, he replies: 'Klar ... Ich krieg jedes Schwein wieder hin' / 'Of course, I can fix any pig' $(L, 115) .{ }^{57}$ Konarske gets a nasty 
surprise when Beate grabs his hand and forces him to feel her breasts $(L, 116)$. In revenge, he prescribes a bath in the lake. He pushes Beate in a tarpaulin-covered wheelbarrow towards the lake, but then he changes course and takes her to a cattle barn instead, where the two of them are completely alone. As Konarske lifts the tarpaulin, there is blood in Beate's mouth, and he enjoys seeing the fear in her eyes $(L, 117)$. Within hours, Beate is dead, never having reached the lake. Although the cause of death is not explicitly stated, it seems likely that Konarske murders her in the cattle barn. Konarske's comment on Beate's death certainly supports this interpretation: 'Sie hat es so gewollt' / 'She wanted it that way' $(L, 118)$, as does the fact that he spends the whole afternoon thinking about the terror in her eyes. Later, when he becomes a doctor, Konarske amuses himself by referring to each patient metonymically, according to his or her medical condition: 'Darmkrebs ... Phlegmone ... Platzwunde ... Beinbruch' / 'bowel cancer ... phlegmon ... laceration ... fractured leg' ( $L, 183)$. He has no desire to understand or ameliorate his patients' psychic distress: 'Konarske verachtete die Seele' / 'Konarske scorned the soul' ( $L$, 391).

Konarske is an active sadist. He gets a sexual thrill from scaring his wife ( $L, 192)$; his nickname for her is 'Mauseprinzessin' / 'mouse princess' $(L, 193,198,199)$. Ominously, this associates her with a laboratory mouse: 'Es ergehe Adele nämlich ähnlich jener Labormaus, welcher Konarske kürzlich mit einem gentechnologischen Eingriff bestimmte Riechzellen aus der Nasenschleimhaut entfernt habe.' / 'Adele's situation resembles that of the mouse from which Konarske recently extracted olfactory cells from the nasal mucous membrane, with the intervention of gene technology' $(L, 202)$. The sensory deprivation of the mouse is analogous to the way in which Konarske deprives Adele of specific information about the research he is conducting on her, infringing her capacity for informed consent.

Given the unsympathetic character of Konarske, readers may be entitled to ask what attracts Adele to him in the first place. The answer seems to lie in the depiction of their troubled, fatherless childhoods. It is significant that Adolf Hitler is symbolically present at the birth of both of the main protagonists. When Gunter is born, Hitler's voice is heard on the radio and, as the midwife presents the baby to the mother, she says: 'Sie haben dem Führer ein schönes Kind geschenkt' / 'You have given the Führer a fine baby' $(L, 20)$. Gunter never meets his father, Doctor Rochus Lingott, an expert in homeopathy who uses herbs from the nearby lake $(L, 10)$. Lingott is arrested by the SA for having failed to display a picture of the Führer in his office; he is never seen again..$^{58}$ The only father figure Gunter knows in his childhood is his maternal grandfather, Otto 
Konarske, an abusive bully. Gunter spends the early years of his life playing with his absent father's medical instruments. Gunter loves to dissect things and when he is only 3 years old his mother Rosie asks him to cut her arm with her nail scissors in a bid to relieve her from her numbness $(L, 66)$. Because of Rosie's silent depression, he learns very little about his father, except what his schoolmates tell him: 'dein Vata is 'n jroßer Zaubara jewesen' / 'your dad was a great magician' $(L, 70)$. This gives him a feeling of superiority over the other children: 'Seit diesem Tag bemerkte Rosie das feine Lächeln um den Mund ihres Sohnes' / 'Ever since that day, Rosie noticed that her son's mouth had acquired a sophisticated smile' $(L, 71)$. Gunter resolves to emulate his father; unfortunately, he lacks his father's kindness.

For Adele, Hitler functions not only as a symbolic godfather, but as an actual father. Her mother Liese tells her that her father is a kind of 'king', and promises to reveal his true identity when her daughter is old enough to understand $(L, 89)$. Over the Christmas of 1954, Adele eavesdrops on her mother and hears her say: 'Mei Madl is doch'n Fiehror sein Kind' / 'My girl is the daughter of the Führer' $(L, 106)$. In the winter of 1943, Hitler visited the town, and she had the honour of preparing potato soup for him $(L, 25)$. When his limousine drove off, Liese chased after it, and she enjoyed a moment of passion in the woods - but was it really with the Führer, or was it with one of the local peasant boys $(L, 27)$ ? Whatever the facts may be, Liese is convinced that her daughter is the child of the Führer, who, after 1945, is still with her in spirit $(L, 80)$. Having revealed Adele's 'noble' lineage, Liese dies and Adele is sent to a children's home. ${ }^{59}$ At the children's home, in 1954, Adele sees a picture of the Führer, and she realises that her father must be the 'Führer' himself $(L, 146)$. Now she understands 'Das Große ihrer Abstammung' / 'the greatness of her ancestry' $(L, 146)$. From this day on, Adele refuses to believe the bad things people say about Hitler - she has at last identified her consoling 'Märchen' / 'fairy tale' $(L, 147)$, which compensates for her isolation and abandonment. Her fantasy is the embodiment of the fascist logic that defines the leader as a powerful father figure.

In Die Unfähigkeit zu trauern (1967), Alexander and Margarete Mitscherlich argued that West Germans had repressed their previous attachment to the authoritarian figure of the Führer, when the Führer had replaced their own ego-ideal. Before 1945, subordination to the Führer and his grand plans had enabled individual Germans to compensate for their feelings of inferiority. The subject's self-sacrifice and abandonment to the authority of the leader was experienced as the realisation of a cherished ideal: 
Indem ich dem Führer folge, ihm Verehrung zolle, verwirkliche ich ein Stück dieses phantasierten Ich-Ideals. Ich nehme an diesem bedeutungsvollen Leben des Führers, an dessen historisch einmaligen Plänen unmittelbar teil, der Führer und seine Bedeutung werden zu einem Teil von mir. ${ }^{60}$

By following the leader and worshipping him, each person realizes something of this fantasied ego-ideal. Each thus shares directly in the highly significant life of the leader and in his historically unique plans; the leader and his importance become part of oneself. ${ }^{61}$

The Mitscherlichs drew on Freud's essay 'Massenpsychologie und IchAnalyse' / 'Group Psychology and the Analysis of the Ego' (1921), which argues that an authoritarian leader occupies the place of the ego-ideal in each of his followers. ${ }^{62}$ According to the Mitscherlichs, Germans experienced their loyalty to the Führer as a form of liberation, although it was in fact the reverse, namely, a form of masochistic bondage: 'Im Zustand ihrer Hörigkeit erniedrigen sich die Massen vor Führerfiguren, um neues Selbstgefühl zu erlangen ... Die akute Verliebtheit in den Führer steigert die masochistische Lustbereitschaft' / 'In this state of bondage, the masses humble themselves before the leader figure more and more, in order to gain self-esteem ... The acute infatuation with the Führer increases the pleasurable masochistic tendency'. ${ }^{63}$ The Mitscherlichs identify this form of love as characteristically German, 'eine deutsche Art zu lieben' / 'a German way of loving' (as Chapter I of their book is titled), and argue that this structural pattern repeated itself in personal attachments even after 1945. Although their analysis focuses on West Germany, it also has implications for East Germans. As Margarete Mitscherlich put it in 1991, the traditional German faith in authority was never seriously called into question during the four decades in which the GDR existed. ${ }^{64}$

The plot of Lärchenau confirms the Mitscherlichs' theory that the traditional 'Autoritätsglaube' / 'faith in authority' continued after 1945. Significantly, both protagonists, Adele Möbius and Gunter Konarske, bear their mother's surname since their fathers were absent. Both are born in 1944 and, as children, both experience neglect. While still a toddler, Adele loves playing at being a housewife, watching over her 'Wohnreich' / 'domestic kingdom' $(L, 82)$ with her dustpan and brush. Liese and her friend Traudel have great expectations for Adele. When Traudel comments that Adele will go far in life, the mother responds: 'Bis zum Führer?' / 'As far as the Führer?' $(L, 82)$. The mother thinks that her daughter will be a bride fit for a Führer. While Adele is raised to believe 
that she is an alpha female, Gunter is raised as an alpha male. Even as a toddler, he is effectively the man of the house. In time, he decides to emulate his father, the 'Zauberer' / 'magician' $(L, 71)$ he never knew. In the absence of their real fathers, these children become fixated on idealised patriarchal figures: Gunter's ego ideal is his deceased father, whereas Adele's ego ideal is Hitler himself. Later, when Adele meets Gunter, he becomes her new idol and she keeps a photograph of him under her mattress, right next to her photo of Hitler $(L, 170)$. Unlike Hitler, however, Gunter's mission is not racial supremacy, but scientific glory.

Adele's relationship with her husband Gunter follows the pattern described by the Mitscherlichs, in which the attachment to an authoritarian leader predisposes the individual to masochistic enjoyment. Adele enjoys the humiliating treatment inflicted on her, or at least, she tries to enjoy it, because it confirms her sense of her own higher calling:

Nach jeder Demütigung, die Konarske seiner Frau verabreichte, fühlte sich diese erweckt. Jede Herablassung, jede Beleidigung verschaffte ihr gleichsam Widerwillen als auch Lust. Nach jedem Kampf gab es nur einen Sieger: Konarske. Aber Adele nannte es Glück.... Doch ... die Menschen waren unfähig zum Staunen über Adeles hohe Zunft.

After every humiliation that Konarske subjected his wife to, she felt aroused. Every condescension, every insult caused her both repulsion and pleasure. After every battle there was only one winner: Konarske. But Adele called it happiness.... And yet, people were unable to marvel at her high calling. $(L, 193)$

In this way, Adele's private humiliation is offset by her sense of devotion to a higher purpose - and by the satisfaction she gets when the villagers address her as 'Frau Doktor' $(L, 186)$. No one else can understand her, because they belong to an inferior species, they have no higher purpose. The characters' sense of superiority over their peers is also reflected in their attempts to lose their dialect and speak only standard German. This process begins when Adele's mother Liese dreams of learning Hochdeutsch / High (or standard) German in order to experience a symbolic connection with the Führer: 'denn im Hauptquartier von Adeles Erzeuger ... würde die reine Sprache der Heiligen gesprochen' / 'In the headquarters of Adele's progenitor, the pure language of the saints was spoken' $(L, 40)$. Linguistic register thus functions here as an instrument of domination. 
Gunter Konarske's narcissism takes precedence over everything else. He has no interest in his son, Timm, because the baby displays no genetic irregularities of any kind: 'Keine Zelle, die dem Gewöhnlichen entwuchs!' / 'No cell which outgrew the ordinary!' $(L, 200)$. This shows once again how Konarske differs ideologically from the Nazis: he has no racial pride, only pride in his own scientific genius. Nevertheless, the underlying attitude is similar: like the Nazis, he regards other people, even members of his own family, as raw material. Because Timm has no scientific interest, for Konarske he is of no interest. Konarske does not seek to control fertility for racial purposes, but only in order to affirm his own scientific superiority. Timm later develops a tendency towards selfharm as a consequence of his neglect by his parents. He falls in with a group of neo-Nazis led by the 'Admiral', Kai. This portrayal of the restrictive, repressive nature of the nuclear family accords with 1970s feminist critiques of patriarchal family structures. ${ }^{65}$

As Sonja Klocke points out, leading medics in the GDR enjoyed special privileges, and this, combined with traditional gender structures, cements Konarske's 'dominant position in the household', ${ }^{66}$ allowing the couple to enjoy the luxuries of a bourgeois lifestyle. The exceptional status of the Konarskes is highlighted when the loyal SED (Socialist Unity Party of Germany) member Elsbeth Giersch comments that the Konarskes are a bourgeois relic:

Die Konarskes, obwohl von denen keiner in der Partei sei, hätten ... eine Riesenküche.... Die Konarskes sind asozial, ein bürgerliches Relikt, das die schwierige Übergangsphase des Sozialismus zum Kommunismus kennzeichne.

Doktor Konarske sah sich veranlaßt, im Frühjahr eine übermannshöhe Hecke um sein Anwesen zu pflanzen.

The Konarskes, although none of them are in the Party, have got an enormous kitchen. The Konarskes are anti-social, a bourgeois relic, characteristic of the difficult phase of transition from socialism to communism. In the spring, Dr Konarske found it necessary to plant a hedge above head height around his estate. $(L, 228)$

This passage emphasises that the Konarskes are exempted from the usual mechanisms of socialisation and participation in the GDR; they live a cloistered existence in a fortress-like house. Despite the egalitarian rhetoric of the GDR, elite members of society still enjoyed a life of privilege; one character even comments 'daß es bei Konarskes inzwischen wie bei Fürstens 
zuginge' / 'the Konarskes live like princes' $(L, 201)$. Despite their extreme wealth, however, their family life appears devoid of warmth and even speech, as the Konarskes barely talk to each other. Their home life resembles the emptiness of Franza's life in Vienna: 'Wir spielten ein königliches Spiel. Schweigen, tun als ob, schweigen, tun als ob' / 'We played a princely game. Silence, pretence, silence, then more pretence'. ${ }^{67}$ Referring to Hensel's early work, Marven has commented that trauma disrupts the use of language, rendering a person mute. ${ }^{68}$ This evaluation certainly seems to apply to Adele, who tries to fill the monotony of her married life by listening to Strauss's opera Der Rosenkavalier / The Knight of the Rose. In this way, we can see how Adele is predisposed towards her own subjugation by the stories she heard from her mother when she was only a small child.

\section{Fertility Experiments and German History as Schweinerei}

Lärchenau spans the entire period of history from around 1930 to the first decade of the twenty-first century. It suggests that the legacy of National Socialism had consequences for the development of the GDR. It also implies that there were limitations to medical ethics in the GDR. In response to crimes committed by medical professionals during the 'Third Reich', the GDR expected doctors to be politically engaged for the 'humane und gerechte Sache' / 'humane and just cause', extending the Hippocratic oath to emphasise a physician's obligation to socialist society in general. ${ }^{69}$ In particular, Lärchenau makes a mockery of the GDR's ambition to breed a new form of socialist human being, likening it to pig breeding on a collectivised farm. The section on pig farming alludes ironically to Christa Wolf's Nachdenken über Christa T. (1968) / The Quest for Christa T. (1979), which features a country vet, Justus, who wants to achieve 'world-class' levels of pork and milk production. ${ }^{70}$ Konarske, although he is not a vet, also wants to use his medical knowledge to boost agricultural production. He tests a new fertility treatment on the swine of the local farmer, Eden, who is now the chairman of the local Landwirtschaftliche Produktionsgenossenschaft (LPG) / Agricultural Production Cooperative ( $L$, 207-9). The pigs become sex-mad; they breed faster and even win prizes. Unfortunately, they die more quickly as well. This episode culminates in a rebellion of the pigs recalling George Orwell's Animal Farm (1945). The pigs are slaughtered, their eyes full of hate $(L, 252)$. The GDR agricultural ministry responds to this disaster by summoning the 'Agraringenieurin' / 'agrarian engineer' Olga Poljuchowa from Moscow, who is tasked with introducing the latest Soviet method of artificial 
insemination $(L, 253)$. This method is tested out on Helmar Eden's prize sow, named 'Liebauge PS 444'/ 'Bright Eyes 444 Horsepower' $(L, 254)$. The method requires Eden to stimulate the sow's erogenous zones while Olga Poljuchowa squirts in the boar's semen $(L, 255)$.

Before the pig serum fails, however, Konarske decides to try it out on a human subject: he slips Krause and his wife nurse Angela the drug it causes Angela to miscarry twice $(L, 222)$. Worse still, Adele accidentally eats some chocolates spiked with the drug. Under the influence, she sleeps with one of the local youths. ${ }^{71}$ Later, Konarske impregnates the soil with genetically modified mycelium in order to grow giant truffles to give to the pigs $(L, 373)$ - at this point the text draws a parallel between the drugged truffles and the medicated chocolate truffles that Adele receives: 'Es ging den Tieren wie Adele' / 'What happened to the animals, happened to Adele' $(L, 374)$. Konarske treats his wife, and nurse Angela, much as he would treat laboratory animals, thus dehumanising them.

The references to pig breeding in Lärchenau suggest associations with Nazi eugenics programmes designed to increase the fertility of preferred races. ${ }^{72}$ However, the fertility programmes in Lärchenau are not underpinned by racial ideology, but by a more covert ideology of scientific neutrality and efficiency. They look ahead to the nightmare eugenics potential of contemporary genetics research. Thanks to the latest human genome editing techniques, scientists now believe that 'the future à la carte medicine is within reach, providing the ability to modify cells, tissues, and organs with high precision. ${ }^{73}$ Modifying human embryos is already legal in China and in many US states. In one recent experiment, Chinese scientists used molecules called CRISPRs (Clustered Regularly Interspaced Short Palindromic Repeats) to cut DNA in human embryos and then 'repair' it by introducing new DNA. The team used non-viable embryos obtained from fertility clinics in an attempt to head off ethical concerns. ${ }^{74}$ Even so, the study provoked considerable debate about the dangers of 'playing god'. ${ }^{75}$ There were calls for a clinical moratorium on these applications, 'while the ethical and safety concerns of human-embryo editing are worked out'. ${ }^{76}$ Jennifer Doudna, an expert in the field of 'gene hacking', confesses that she has dreamed about meeting Hitler:

'I had a dream recently, and in my dream' - she mentioned the name of a leading scientific researcher - "had come to see me and said, "I have somebody very powerful with me who I want you to meet, and I want you to explain to him how this technology functions." So I said, Sure, who is it? It was Adolf Hitler. I was really horrified, but I went 
into a room and there was Hitler. He had a pig face and I could only see him from behind and he was taking notes and he said, "I want to understand the uses and implications of this amazing technology." I woke up in a cold sweat. And that dream has haunted me from that day. Because suppose somebody like Hitler had access to this - we can only imagine the kind of horrible uses he could put it to.'77

Genetics research of the twenty-first century has a destructive potential that is incalculable, and it remains haunted by the spectre of Nazi eugenics.

\section{After Reunification: Genetic Experiments and Anti-Age Serum}

In the last third of the novel, covering the post-reunification period from 1990 to 2007, Konarske's position of authority remains unchallenged, and he further extends his dominance over Adele. At this point he starts to present the characteristics associated with the legendary Bluebeard figure: he starts to keep her locked in a chamber of the house, and he has a private laboratory in the basement of his house that his wife and son are forbidden to enter. The reference to Bluebeard is an allusion to Bachmann's Das Buch Franza, but it also points towards a broader patriarchal discourse, as Mererid Puw Davies has shown. ${ }^{78}$ Konarske now starts injecting Adele with an experimental youth serum in an attempt to win the Nobel Prize. The rejuvenation serum can be interpreted in a number of different ways. On one level, as Klocke suggests, it can be read as an allegory of Western consumerism with its cult of youth and its cosmetics industry, with its artificial attempts to preserve youthful appearances. ${ }^{79}$ On another level, as Garbiñe Iztueta argues, Adele's artificial rejuvenation could suggest the post-Wende federal German government's treatment of East Germany. According to Iztueta, Adele's body symbolises 'the manipulated and unnatural "rebirth" of the weak, dying GDR into a new, renovated and polished Federal Republic, injected and revitalised with capitalism's "vitamin serum"'. ${ }^{80}$ In this sense, the brutal power relationship implied by the reversal of Adele's aging process in Lärchenau alludes to the idea that the GDR was effectively 'colonised' by the FRG in $1990 .{ }^{81}$ On yet another level, a gendered reading of the youth serum suggests that it is an allegory of the infantilisation of women under patriarchy, and particularly within bourgeois marriage. Hermann Glaser notes the German conservative preference for the figure of Gretchen in Goethe's Faust I, the adolescent country girl seduced by the older, more experienced man. 
Glaser argues that, instead of Goethe's sovereign women, Helena and Iphigenie, German reactionaries always preferred Gretchen, depicted as 'ein sauberes Mädchen in einem sauberen Stübchen' / 'a clean little girl in a clean little room'. ${ }^{82}$ This Gretchen cult inaugurated a reactionary ideology of chastity, which cast women as wayward girls who had to be brought to heel by marriage, ${ }^{83}$ and in which the word 'Mädel' functions as a code word for the reversal of female emancipation. ${ }^{84}$ This is what Konarske does to Adele: he takes a bold, ambitious woman and reduces her to a weak, vulnerable child. The Faustian hero creates his own Gretchen by artificial means.

By the end of the novel, Adele effectively resembles a 6-year-old girl. She escapes from her room and smashes up her husband's private laboratory. Then she runs away into the woods and is murdered by three men who speak Russian. The name of Adele's murderer is, ironically, Oleg, which is also the name of the Russian soldier who saved her after the Second World War. This recalls the Kleistian dichotomy in Die Marquise von O. / The Marquise of O., in which the male figure, Graf F., also a Russian officer, alternates between two opposing faces: the angelic saviour and the demonic predator. As in Kleist's tale, the figures of Oleg and Gunter Konarske suggest the duality of the patriarchal male figure, who harbours the potential to save or to destroy the female character whom he is supposed to 'protect'.

Klocke has shown that the final section of Hensel's novel references a debate that occurred in the German media in 1999, when the philosopher Peter Sloterdijk gave a speech, 'Regeln für den Menschenpark' / 'Rules for the Human Zoo', in which he claimed that the humanist project of 'taming' humans by means of education had failed; instead he called for selective genetic breeding to take on the tasks that humanism has failed to fulfil. ${ }^{85}$ Sloterdijk's call for the manipulation of human DNA reminded many of Nazi eugenics programmes, and his controversial remarks were debated in Der Spiegel and Die Zeit. ${ }^{86}$ On 27 September 1999, the front cover of Der Spiegel bore the headline 'Gen-Projekt Übermensch' / 'Gene-Project Superman'. Inside was a long essay on human gene manipulation, including a warning from the US molecular biologist Liebe F. Cavalieri: genetic design will be 'more significant than splitting the atom, and no less dangerous' ${ }^{87}$ Page 312 of the same article featured the image of a mouse implanted with a human ear. Lärchenau alludes to this controversy when Konarske produces a mouse with a human eye on its back $(L, 293)$. Subsequent comments in the letters page of Der Spiegel appeared under the title 'Gentechnik als Zaubermittel' / 'Gene Technology as a Magical Cure', making the same connection 
between genetics and magic that Hensel makes in Lärchenau. ${ }^{88}$ The brave new world conjured up by Sloterdijk, in which geneticists engineer an improved version of humanity, is refuted in Hensel's novel, which shows the cruel, sadistic side of genetic research. Lärchenau suggests the dangers involved when privileged physicians are allowed to play God and experiment on human beings. Significantly, Konarske's experiments on his wife become more radical in the years after German reunification, suggesting that, since 1990, medical research has become deregulated as a result of privatisation and globalisation, and lends itself to abuse even more than under the previous socialist system. Konarske's West German colleague, Dickescheidt, later wins the Nobel Prize. In this way, the novel suggests that practices associated with Nazi racial science have persisted, even as the racial ideology that informed them has faded.

The dehumanisation of the female characters and the unethical human experimentation described in Lärchenau suggest the need for continuing debate about the ethics of medical research and the violence that occurs when some human beings are considered more valuable than others. In Lärchenau, the characters abuse their power. Konarske abuses his authority as a doctor; Hanswerner Giersch takes advantage of his position as a Stasi officer to abuse another character, Helge Hemlock, sexually; and 'Admiral' Kai uses his neo-Nazi followers as cannon fodder for a suicide mission. This situation underscores the dangers of patriarchal authority, as hierarchies are continually reproduced and members of the underclass are encouraged to abdicate responsibility for their own lives and to put their trust in scientific and political elites. This state of affairs resembles the situation of 'Bevormundung' / 'tutelage', which Immanuel Kant describes in 'Was ist Aufklärung?' / 'What is Enlightenment?' (1784). Kant's essay examines how people abdicate responsibility and allow their lives to be controlled by 'jene Vormünder, die die Oberaufsicht ... gütigst auf sich genommen haben'/ 'those guardians who have kindly taken supervision upon themselves. ${ }^{89}$ Hensel's Lärchenau gives readers a literal image of tutelage, as an adult woman is artificially reverted to childhood. Not only is Adele reduced to the moral status of a child, she is also reduced to the physical condition of a child. Her physical condition is the embodiment of her psychic absorption by her husband, her acquiescence in his authority. When she finally rebels at the end of the novel, she is murdered by male predators.

The engagement with German history in Hensel's Lärchenau offers lessons for the present. Lärchenau shows recurrent patterns of abusive relationships between victims and perpetrators. Only recently have historians such as Weindling conducted sustained research into the 
testimonies of the victims of Nazi medical atrocities. In this respect, fictions by Hensel (and Bachmann) are ahead of their time, not only because they sketch out investigative, hypothetical approaches to uncomfortable issues of perpetration and collaboration, but also because they explore the long-term effects of post-traumatic stress on the victims themselves.

Lärchenau invites its readers to reflect on the politics of the present day. ${ }^{90}$ It reminds us that eugenics is firmly back on the agenda in contemporary Germany, as is evident from the racist bestsellers of Thilo Sarrazin and the racist policies of Alternative für Deutschland (AfD). ${ }^{91}$ On 11 January 2017, André Wendt, an AfD delegate in the regional parliament in Saxony, enquired about the costs of sterilisation programmes for under-age migrants. ${ }^{92}$ In the context of a shift towards the right in Germany and 'the West', Lärchenau is salutary reading. Although published five years before the AfD came into existence in 2013, the novel is a powerful antidote to the new far right in Germany. It even has a subplot in which Adele's son Timm joins a group of neo-Nazis, and dies in a botched military manoeuvre. This scenario echoes Grass's novella Im Krebsgang / Crabwalk (2002), which relates the story of Konny, the grandson of an East Prussian expellee who becomes a neo-Nazi, and Bachmann's notes for her planned Todesarten / Ways of Dying project, of which Das Buch Franza was to form part, which describe three neoNazi youths who murder each other in the forest. ${ }^{93}$ Hensel's Lärchenau implies that these fascist behaviour patterns will be repeated by following generations, unless they are addressed. Those who do not learn from history will repeat it. ${ }^{94}$ In this sense, Hensel's novel makes a vital contribution to the task of Erinnerungsarbeit / memory work. It excavates the moral minefield of German history precisely because it wants to defuse some of the unexploded bombs (and poisonous ideologies) still present today.

Let us conclude by returning to the point about literary genre. Literary critics often operate with genre categories, and, as we have seen, there is a tendency to pigeonhole Hensel as a grotesque satirist. Grotesque satire is certainly one element among others in her repertoire. However, such categorisation does Hensel a real disservice, because it consigns her to a genre that is considered inferior in status. This form of labelling is ultimately reductive. It prescribes a narrow interpretive horizon, and stands in the way of a serious consideration of her complex, challenging work. The same holds true for interpretations that foreground Hensel's use of fantasy elements. While Iztueta's analysis of Lärchenau unpacks many of the political implications of Hensel's text, it might be possible to question her appraisal of Lärchenau as belonging to 
the genre of the 'Gothic supernatural'. ${ }^{95}$ The medical atrocities depicted in Lärchenau are outrageous and bizarre, but this does not mean that they are unrealistic. A glance at the historical record of Nazi medicine invites a different interpretation of Lärchenau, not as a satire or a gothic fantasy, but as a lucid reflection on the repercussions of the worst medical abuses in human history.

\section{Notes}

1. Hensel, Lärchenau (2008). Further references appear in the text, preceded by the abbreviation ' $L$ '. Unless otherwise specified, all translations in this chapter are mine.

2. Mitscherlich and Burmeister, Wir haben ein Berührungstabu.

3. Bachmann, Das Buch Franza, 124.

4. Bachmann, The Book of Franza, 128.

5. Mitscherlich and Mielke, Das Diktat der Menschenverachtung. Revised edition: Medizin ohne Menschlichkeit. English edition: The Death Doctors.

6. Nicosia and Huener, 'Introduction: Nazi Medicine in Historiographical Context', 1.

7. Schmidt, Selektion in der Heilanstalt, 1939-1945; Klee, "Euthanasie" im NS-Staat; Bock, Zwangssterilisation; Lifton, The Nazi Doctors; Müller-Hill, Murderous Science; Proctor, Racial Hygiene; Kater, Doctors Under Hitler; Gallagher, By Trust Betrayed.

8. Friedlander, The Origins of the Nazi Genocide.

9. Weindling, 'Nazi Human Experiments, 251.

10. Bachmann, Das Buch Franza, 187.

11. Bachmann, The Book of Franza, 85.

12. Bachmann, Das Buch Franza, 183.

13. Bachmann, The Book of Franza, 85.

14. Bachmann, Das Buch Franza, 65.

15. Bachmann, Das Buch Franza, 126.

16. Bird, Women Writers, 27.

17. Bird, Women Writers, 35.

18. Mitscherlich and Mitscherlich, Die Unfähigkeit zu trauern; The Inability to Mourn.

19. Haug, Sexualisierung der Körper, 11.

20. Koonz, Mothers in the Fatherland.

21. For a summary of the debate, see Leck, 'Theoretical Issues'.

22. Compare Stoehr, “'Organisierte Mütterlichkeit”".

23. Kerstin Hensel, Karzinom (second version, 1981). Kerstin-Hensel-Archiv der Akademie der Künste, Berlin. Vorläufige Signatur 4, Ordner 'Dramatik'.

24. Mitscherlich, Auf dem Weg zur vaterlosen Gesellschaft / Society Without A Father.

25. Bachmann, Malina, 290 / Malina, 182.

26. Dahlke, 'Weibliche Männer, männliche Weiber', 68.

27. In Das Buch Franza there is also a character called Prohaska: he is one of Jordan's junior colleagues. Compare Bachmann, Das Buch Franza, 59-61.

28. Twark, 'Negotiating the Politics and Aesthetics of Satire', 139.

29. Compare Nicole Henneberg, 'Kerstin Hensel: Da hört die Jeschichte uff', Der Tagesspiegel, 28 May 2008 http://www.tagesspiegel.de/kultur/literatur/kerstin-hensel-da-hoert-diejeschichte-uff/1243246.html (accessed 14 July 2019).

30. Marven, Body and Narrative, 10.

31. Twark, Humor, Satire, and Identity, 247.

32. On the connection with Grass, see Stephan, 'Laudatio Kerstin Hensel', 156.

33. On the link with Morgner, see Marven, 'The Trobadora's Legacy'.

34. Twark, Humor, Satire, and Identity, 198.

35. Twark, 'Negotiating the Politics and Aesthetics of Satire', 139.

36. On the connections between Übermensch and Neuer Mensch, see Twark, Humor, Satire, and Identity, 247 (footnote 78). 
37. Compare Ulrich Rüdenauer, 'Untertan, Untertänchen. Kerstin Hensel erzählt in ihrem Roman Falscher Hase deutsche Lebensläufe', Der Tagesspiegel, 2 March 2005. http://www.tagesspiegel. de/kultur/untertan-untertaenchen-kerstin-hensel-erzaehlt-in-ihrem-roman/589110.html (accessed 14 July 2019).

38. Schröter, Heinrich Mann, 9-16.

39. Tucholsky, 'Mit Rute und Peitsche durch Preußen-Deutschland'.

40. Compare Dyck and Stewart, The Uses of Humans in Experiment.

41. Compare Homedes and Ugalde, Clinical Trials in Latin America.

42. Weindling, 'German Eugenics', 314.

43. Weindling, 'German Eugenics', 320-1.

44. Weindling, 'German Eugenics', 321-2.

45. Weindling, 'German Eugenics', 325.

46. Hensel's novel may contain an allusion to this history in the description of the notorious collection of preserved foetuses in the Charité hospital in Berlin.

47. Lifton, The Nazi Doctors, 43.

48. Bock, Zwangssterilisation, 376, 453.

49. Lifton, The Nazi Doctors, 274.

50. Lifton, The Nazi Doctors, 274.

51. Lifton, The Nazi Doctors, 271-2.

52. Lifton, The Nazi Doctors, 277. For testimonies of the victims of this procedure, see Bock, Zwangssterilisation, 455.

53. Lifton, The Nazi Doctors, 277.

54. Lifton, The Nazi Doctors, 43.

55. Lifton, The Nazi Doctors, 277.

56. Weindling, 'German Eugenics', 327.

57. The name 'Beate' derives from the Latin name 'Beatrix', meaning 'she who makes happy'. This is appropriate, given that she serves to gratify Konarske's sadistic tendencies.

58. Above his office desk, Rochus Lingott has a botanical print of Wasserschierling (cicuta virosa, northern water hemlock). The hemlock confirms his association with paganism, witchcraft and wizardry.

59. The children's home is named 'Anton Semjonowitsch Makarenko' after the pioneering Soviet educator of the 1920s.

60. Mitscherlich and Mitscherlich, Die Unfähigkeit zu trauern, 72.

61. Mitscherlich and Mitscherlich, The Inability to Mourn, 57.

62. Freud, 'Massenpsychologie und Ich-Analyse', 145. Compare Mitscherlich and Mitscherlich, Die Unfähigkeit zu trauern, 73.

63. Mitscherlich and Mitscherlich, Die Unfähigkeit zu trauern, 74.

64. Mitscherlich and Burmeister, Wir haben ein Berührungstabu, 10.

65. Compare Reichardt, Authentizität und Gemeinschaft; Barrett and McIntosh, The Anti-Social Family.

66. Klocke, Inscription and Rebellion, 161.

67. Bachmann, Das Buch Franza, 187.

68. Marven, Body and Narrative, 10.

69. Klocke, Inscription and Rebellion, 160.

70. Wolf, Nachdenken über Christa T., 141.

71. This part of the plot alludes to Adele's favourite opera, Strauss's Der Rosenkavalier / The Knight of the Rose.

72. The racial theories of the Nazis can be traced back to Social Darwinism and early eugenicists such as Francis Galton (1822-1911). Compare Turda, 'Race, Science, and Eugenics'.

73. Tobita et al., 'From Hacking the Human Genome', 174.

74. Cyranoski and Reardon, 'Embryo Editing', 593.

75. Tobita et al., 'From Hacking the Human Genome', 179.

76. Cyranoski and Reardon, 'Embryo Editing', 594.

77. Specter, 'The Gene Hackers'.

78. Davies, The Tale of Bluebeard in German Literature.

79. Klocke, Inscription and Rebellion, 163.

80. Iztueta, 'Body and Grotesque', 157.

81. Iztueta, 'Body and Grotesque', 159.

82. Glaser, Spießer-Ideologie, 171. 
83. Glaser, Spießer-Ideologie, 172: 'Ein Jahrhundert der "sorgsamen Gattinnen, treuen Mütter, frommen und keuschen Töchter" brach an, ein Jahrhundert der Keuschheitsideologie.' / 'A century of "caring spouses, faithful mothers and pious and chaste daughters" had begun, ... a century of chastity worship.' (Translation: Glaser, The Cultural Roots of National Socialism, 179.)

84. Glaser, Spießer-Ideologie, 171: 'Die ... Emanzipation der Frau wird rückgängig gemacht, ihre Entwertung und Entpersönlichung zu einem Element der deutschen Ideologie. "Mädel" ist ein Stichwort für diesen Vorgang'. / 'The process of female emancipation ... was reversed, her degradation and depersonalization became an element of German ideology. "Mädel" (maiden) is a key word in this process.' (Translation: Glaser, The Cultural Roots of National Socialism, 178.)

85. Klocke, Inscription and Rebellion, 158. Sloterdijk's claim that humanism tries to 'tame' human beings arguably shows that he wilfully misunderstands humanism.

86. Klocke, Inscription and Rebellion, 158.

87. Marco Evers, Klaus Franke and Johann Grolle, 'Zucht und deutsche Ordnung', Der Spiegel, 39 (27 September 1999), 300-16 (303).

88. 'Briefe: Gentechnik als Zaubermittel' Der Spiegel 41 (11 October 1999), 8.

89. Kant, 'Beantwortung der Frage: Was ist Aufklärung?', in Kant, Was ist Aufklärung?, 55. English translation: http://www.columbia.edu/acis/ets/CCREAD/etscc/kant.html (accessed 14 July 2019). On Kant's essay in the context of this volume's concerns, see also Mererid Puw Davies's chapter.

90. For a reading of Hensel in terms of eco-criticism, see Probst, Vakante Landschaft.

91. On Thilo Sarrazin, see Stanicic, Anti-Sarrazin.

92. Danys, 'Sterilisation von Flüchtlingskindern?'.

93. Bachmann, 'Todesarten'-Projekt, III.2, 713-6.

94. Mitscherlich and Burmeister, Wir haben ein Berührungstabu, 10.

95. Iztueta, 'Body and Grotesque', 145-6.

\section{Bibliography}

Bachmann, Ingeborg. Malina: Roman. Frankfurt am Main: Suhrkamp, 1980.

Bachmann, Ingeborg. Malina: A Novel, translated by Philip Boehm. New York: Holmes and Meier, 1990.

Bachmann, Ingeborg. The Book of Franza and Requiem for Fanny Goldmann, translated by Peter Filkins. Evanston, IL: Northwestern University Press, 1999.

Bachmann, Ingeborg. Das Buch Franza; Requiem für Fanny Goldmann, edited by Monika Albrecht and Dirk Göttsche. Munich: Piper, 2004.

Bachmann, Ingeborg. 'Todesarten'-Projekt: Kritische Ausgabe, edited by Monika Albrecht and Dirk Göttsche, 4 vols. Munich: Piper, 2005.

Barrett, Michèle and Mary McIntosh. The Anti-Social Family. London: NLB, 1982.

Bird, Stephanie. Women Writers and National Identity: Bachmann, Duden, Özdamar. Cambridge: Cambridge University Press, 2003.

Bock, Gisela. Zwangssterilisation im Nationalsozialismus: Studien zur Rassenpolitik und Frauenpolitik. Opladen: Westdeutscher Verlag, 1986.

Cyranoski, David and Sara Reardon. 'Embryo Editing Sparks Epic Debate', Nature 520, no. 7549 (2015): 593-94.

Dahlke, Birgit. 'Weibliche Männer, männliche Weiber: Gender in Transit'. In Kerstin Hensel (Contemporary German Writers), edited by Beth Linklater and Birgit Dahlke, 67-77. Cardiff: University of Wales Press, 2002.

Danys, David. 'Sterilisation von Flüchtlingskindern?', Der Freitag, 14 February 2017. Accessed 29 September 2019. https://www.freitag.de/autoren/david-danys/sterilisation-von-fluechtlingskindern.

Davies, Mererid Puw. The Tale of Bluebeard in German Literature: From the Eighteenth Century to the Present. Oxford: Oxford University Press, 2001.

Dyck, Erika and Larry Stewart, ed. The Uses of Humans in Experiment: Perspectives from the 17th to the 20th Century. Leiden: Brill, 2016. 
Freud, Sigmund. 'Massenpsychologie und Ich-Analyse'. In Gesammelte Werke, Band XIII, by Sigmund Freud, 71-161. Frankfurt am Main: Fischer, 1987.

Friedlander, Henry. The Origins of the Nazi Genocide: From Euthanasia to the Final Solution. Chapel Hill: University of North Carolina Press, 1995.

Gallagher, Hugh Gregory. By Trust Betrayed: Patients, Physicians, and the License to Kill in the Third Reich. New York: H. Holt, 1990.

Glaser, Hermann. Spießer-Ideologie: Von der Zerstörung des deutschen Geistes im 19. und 20. Jahrhundert und dem Aufstieg des Nationalsozialismus. Frankfurt am Main: Fischer, 1986.

Glaser, Hermann. The Cultural Roots of National Socialism, translated by Ernest A. Menze. London: Croom Helm, 1978.

Haug, Frigga, ed. Sexualisierung der Körper (Frauenformen). Berlin: Argument-Verlag, 1983.

Hensel, Kerstin. Lärchenau: Roman. Munich: btb, 2010.

Homedes, Nuria and Antonio Ugalde, eds. Clinical Trials in Latin America: Where Ethics and Business Clash. Cham: Springer, 2014.

Iztueta, Garbiñe. 'Body and Grotesque as Self-Disruption in Kerstin Hensel's Gothic East(ern) German Novel Lärchenau (2008)'. In Strategies of Humor in Post-Unification German Literature, Film, and Other Media, edited by Jill E. Twark, 143-64. Newcastle upon Tyne: Cambridge Scholars Publishing, 2011.

Kant, Immanuel. Was ist Aufklärung? Aufsätze zur Geschichte und Philosophie. 4th ed. Göttingen: Vandenhoeck und Ruprecht, 1994.

Kater, Michael H. Doctors under Hitler. Chapel Hill: University of North Carolina Press, 1989.

Klee, Ernst. "Euthanasie" im NS-Staat: Die "Vernichtung lebensunwerten Lebens". Frankfurt am Main: Fischer, 1983.

Klocke, Sonja E. Inscription and Rebellion: Illness and the Symptomatic Body in East German Literature. Rochester, NY: Camden House, 2015.

Koonz, Claudia. Mothers in the Fatherland: Women, the Family, and Nazi Politics. New York: St Martin's Press, 1986.

Leck, Ralph M. 'Theoretical Issues: Conservative Empowerment and the Gender of Nazism: Paradigms of Power and Complicity in German Women's History', Journal of Women's History 12, no. 2 (2000): 147-69.

Lifton, Robert Jay. The Nazi Doctors: Medical Killing and the Psychology of Genocide. London: Macmillan, 1986.

Marven, Lyn. Body and Narrative in Contemporary Literatures in German: Herta Müller, Libuše Moníková, and Kerstin Hensel. Oxford: Clarendon Press, 2005.

Marven, Lyn. 'The Trobadora's Legacy: Two Generations of GDR Women Writers'. In Women's Writing in Western Europe: Gender, Generation and Legacy, edited by Adalgisa Giorgio and Julia Waters, 54-68. Newcastle upon Tyne: Cambridge Scholars Publishing, 2007.

Mitscherlich, Alexander. Society without the Father: A Contribution to Social Psychology, translated by Eric Mosbacher. New York: Schocken Books, 1970.

Mitscherlich, Alexander. Auf dem Weg zur vaterlosen Gesellschaft: Ideen zur Sozialpsychologie. Munich: Piper, 1973.

Mitscherlich, Alexander and Fred Mielke. Das Diktat der Menschenverachtung: Eine Dokumentation. Heidelberg: Lambert Schneider, 1947.

Mitscherlich, Alexander and Fred Mielke. Medizin ohne Menschlichkeit: Dokumente des Nürnberger Ärzteprozesses. Frankfurt am Main: Fischer, 1960.

Mitscherlich, Alexander and Fred Mielke. The Death Doctors, translated by James Cleugh. London: Elek Books, 1962.

Mitscherlich, Alexander and Margarete Mitscherlich. The Inability to Mourn: Principles of Collective Behavior, translated by Beverley R. Placzek. New York: Grove Press, 1975.

Mitscherlich, Alexander and Margarete Mitscherlich. Die Unfähigkeit zu trauern: Grundlagen kollektiven Verhaltens. Munich: Piper, 2012.

Mitscherlich, Margarete and Brigitte Burmeister. Wir haben ein Berührungstabu. Hamburg: Klein Verlag, 1991.

Müller-Hill, Benno. Murderous Science: Elimination by Scientific Selection of Jews, Gypsies, and Others, Germany, 1933-1945, translated by George Fraser. Oxford: Oxford University Press, 1987.

Nicosia, Francis R. and Jonathan Huener. 'Introduction: Nazi Medicine in Historiographical Context'. In Medicine and Medical Ethics in Nazi Germany: Origins, Practices, Legacies, edited by Francis R. Nicosia and Jonathan Huener, 1-12. New York: Berghahn Books, 2008. 
Probst, Inga. Vakante Landschaft: Postindustrielle Geopoetik bei Kerstin Hensel, Wolfgang Hilbig und Volker Braun. Würzburg: Königshausen \& Neumann, 2016.

Proctor, Robert. Racial Hygiene: Medicine under the Nazis. Cambridge, MA: Harvard University Press, 1988.

Reichardt, Sven. Authentizität und Gemeinschaft: Linksalternatives Leben in den siebziger und frühen achtziger Jahren. Berlin: Suhrkamp, 2014.

Schmidt, Gerhard. Selektion in der Heilanstalt, 1939-1945. Stuttgart: Evangelisches Verlagswerk, 1965.

Schröter, Klaus. Heinrich Mann: “Untertan” - "Zeitalter" - Wirkung: Drei Aufsätze. Stuttgart: Metzler, 1971.

Specter, Michael. 'The Gene Hackers', The New Yorker, 16 November 2015. Accessed 27 September 2019. https://www.newyorker.com/magazine/2015/11/16/the-gene-hackers.

Stanicic, Sascha. Anti-Sarrazin: Argumente gegen Rassismus, Islamfeindlichkeit und Sozialdarwinismus. Cologne: PapyRossa, 2011.

Stephan, Inge. 'Laudatio Kerstin Hensel'. In Kerstin Hensel (Contemporary German Writers), edited by Beth Linklater and Birgit Dahlke, 153-61. Cardiff: University of Wales Press, 2002.

Stoehr, Irene. “'Organisierte Mütterlichkeit”: Zur Politik der deutschen Frauenbewegung um 1900'. In Frauen suchen ihre Geschichte: Historische Studien zum 19. und 20. Jahrhundert, edited by Karin Hausen, 221-49. Munich: C.H. Beck, 1983.

Tobita, Takamasa, Jorge Guzman-Lepe and Alexandra Collin de l'Hortet. 'From Hacking the Human Genome to Editing Organs', Organogenesis 11, no. 4 (2015): 173-82.

Tucholsky, Kurt. 'Mit Rute und Peitsche durch Preußen-Deutschland'. In Heinrich Mann: Texte zu seiner Wirkungsgeschichte in Deutschland, edited by Renate Werner, 113. Munich: Deutscher Taschenbuch Verlag, 1977.

Turda, Marius. 'Race, Science, and Eugenics in the Twentieth Century'. In The Oxford Handbook of the History of Eugenics, edited by Alison Bashford and Philippa Levine, 62-79. Oxford: Oxford University Press, 2010.

Twark, Jill E. Humor, Satire, and Identity: Eastern German Literature in the 1990s. Berlin: Walter de Gruyter, 2007.

Twark, Jill E. 'Negotiating the Politics and Aesthetics of Satire: Satirical Novels in the GDR and Beyond'. In Rereading East Germany: The Literature and Film of the GDR, edited by Karen Leeder, 126-42. Cambridge: Cambridge University Press, 2015.

Weindling, Paul. 'German Eugenics and the Wider World: Beyond the Racial State'. In The Oxford Handbook of the History of Eugenics, edited by Alison Bashford and Philippa Levine, 315-31. Oxford: Oxford University Press, 2010.

Weindling, Paul. 'Nazi Human Experiments: The Victims' Perspective and the Post-Second World War Discourse'. In The Uses of Humans in Experiment: Perspectives from the 17th to the 20th Century, edited by Erika Dyck and Larry Stewart, 240-59. Leiden: Brill, 2016.

Wolf, Christa. Nachdenken über Christa T. Munich: Deutscher Taschenbuch Verlag, 1997. 
that they hold a power of decision-making over their time and activities, that they are their own boss, and that they can feel capable and set their own boundaries in their lives.

28. Email conversation with the film-maker, March 2017.

\section{Bibliography}

Bröckling, Ulrich. Das unternehmerische Selbst: Soziologie einer Subjektivierungsform. 5th ed. Frankfurt am Main: Suhrkamp, 2013.

Büttner, Christoph. "'In dir muss brennen!": Self/Change-Management in Arbeitswelt und Dokumentarfilm'. In Opus und labor: Arbeit in autobiographischen und biographischen Erzählungen (Schriften des Fritz-Hüser-Instituts für Literatur und Kultur der Arbeitswelt 31), edited by Iuditha Balint, Katharina Lammers, Kerstin Wilhelms and Thomas Wortmann, 191-212. Essen: Klartext, 2018.

Chen, Mel Y. and Dana Luciano, eds. Queer Inhumanisms (Special issue of GLQ: A Journal of Lesbian and Gay Studies 21, no. 2/3). Durham, NC: Duke University Press, 2015.

Crary, Jonathan. 24/7: Late Capitalism and the Ends of Sleep. London: Verso, 2013.

Dernbach, Rafael. 'The Uncanny of Surveillance: Architectures of Hyperactive Incapacity in Nikolaus Geyrhalter's Abendland and Falk Richter's Unter Eis'. In Architecture and Control, edited by Annie Ring, Henriette Steiner and Kristin Veel, 46-64. Leiden: Brill, 2018.

Farocki, Harun. (dir., 2012) Ein neues Produkt (documentary, Germany).

Flowmanagement, webpage. Accessed 17 September 2018. http://www.clamosca.ch.

Foucault, Michel. Security, Territory, Population: Lectures at the Collège de France, 1977-78, edited by Michel Senellart; translated by Graham Burchell. Basingstoke: Palgrave Macmillan, 2007.

Gartner-Steffen Coaching und Konfliktberatung, webpage. Accessed 17 September 2018. http:// www.gartner-steffen.de.

Gianfranco Baruchello: Cold Cinema. Film, video e opere 1960-1999. Exhibition held at La Triennale di Milano, 9 December 2014-22 February 2015.

Han, Byung-Chul. Müdigkeitsgesellschaft. Berlin: Matthes und Seitz, 2010.

Lethen, Helmut. Verhaltenslehren der Kälte: Lebensversuche zwischen den Kriegen. Frankfurt am Main: Suhrkamp, 1994.

Lethen, Helmut. Cool Conduct: The Culture of Distance in Weimar Germany, translated by Don Reneau. Berkeley: University of California Press, 2002.

Losmann, Carmen. (dir., 2012) Work Hard - Play Hard (documentary, Germany).

Pethke, Katharina (dir., 2009) In dir muss brennen (documentary, Germany).

Plessner, Helmuth. Grenzen der Gemeinschaft: Eine Kritik des sozialen Radikalismus. Frankfurt am Main: Suhrkamp, 2002.

Proctor, Andrew and Elizabeth Proctor. The Essential Guide to Burnout: Overcoming Excess Stress. Oxford: Lion, 2013.

Ring, Annie. 'System Error: Complicity with Surveillance in Contemporary Workplace Documentaries', Seminar: A Journal of Germanic Studies 52, no. 4 (2016): 465-89.

Schaffner, Anna Katharina. Exhaustion: A History. New York: Columbia University Press, 2016.

Schmitt, Carl. Politische Theologie: Vier Kapitel zur Lehre von der Souveränität. 6th ed. Berlin: Duncker und Humblot, 1993.

Selye, Hans. Stress without Distress. Philadelphia: Lippincott, 1974.

Shaw, Deborah. '(Trans)national Images and Cinematic Spaces: The Cases of Alfonso Cuarón's Y tu mamá también (2001) and Carlos Reygadas' Japón (2002)', Iberoamericana 11, no. 44 (2011): 117-31.

Simmel, Georg. 'Die Großstädte und das Geistesleben'. In Aufsätze und Abhandlungen 1901-1908, Band I, edited by Rüdiger Kramme, Angela Rammstedt and Otthein Rammstedt, 116-31. Frankfurt am Main: Suhrkamp, 1995.

Wehrle, Martin. “"Bleibst du auf der Strecke, liegt es nur an dir!”', Der Spiegel, 10 October 2013. Accessed 18 June 2018. http://www.spiegel.de/karriere/martin-wehrle-ueber-die-arbeitsweltder-globalisierung-a-926817.html.

Wehrle, Martin. Bin ich hier der Depp? Wie Sie dem Arbeitswahn nicht länger zur Verfügung stehen. Munich: Goldmann, 2016. 

Medical Humanity and Inhumanity in the German-Speaking World is the first volume dedicated to exploring the interface of medicine, the human and the humane in the German-speaking lands.

The volume tracks the designation and making through medicine of the human and inhuman, and the humane and inhumane, from the Middle Ages to the present day. Eight individual chapters undertake explorations into ways in which theories and practices of medicine in the German-speaking world have come to define the human, and highlight how such theories and practices have consolidated, or undermined, notions of humane behaviour. Cultural analysis is central to this investigation, foregrounding the reflection, refraction and indeed creation of these theories and practices in literature, life-writing and other discourses and media.

Contributors bring to bear perspectives from literary studies, film studies, critical theory, cultural studies, history, and the history of medicine and psychiatry. Thus, this collection is historical in the most expansive sense, for it debates not only what historical accounts bring to our understanding of this topic. It encompasses too investigation of life-writing, documentary, and theory and literary works to bring to light elusive, paradoxical, underexplored - yet vital - issues in history and culture.

Mererid Puw Davies is Associate Professor in German at UCL. She has published widely on modern German-language literature, film, cultural and comparative studies. Her publications include The Tale of Bluebeard in German Literature from the Eighteenth Century to the Present (2001) and Writing and the West German Protest Movements (2016).

Sonu Shamdasani is Vice-Dean (International) of the Faculty of Arts and Humanities and Co-Director of the UCL Health Humanities Centre. He works on the history of psychology and psychiatry. He has written six monographs and edited six volumes, which have together been translated into more than 20 languages. 